\title{
Intercultural Ritual Transgression as a Catalyst for Early Christian Theological Reflection - A Consideration of 1 Corinthians 8
}

\author{
Peter-Ben Smit \\ Vrije Universiteit Amsterdam, The Netherlands; Utrecht University, Utrecht; \\ University of Pretoria, Pretoria \\ p.b.a.smit@vu.nl
}

\begin{abstract}
What led to the issues that Paul addresses in 1 Corinthians 8? This paper argues that the missionary expansion of the early community led to a renegotiation of its ritual boundaries, in particular concerning question of ritual participation. Theory concerning 'ritual failure' is used in order to analyse the dynamics involved.
\end{abstract}

\section{Keywords}

mission - early Christianity - ritual - Eucharist - meals

\section{Introduction}

The question of (transgressive and intercultural) ritual participation, in the sense of participation in rituals across ethnic / cultural and cultic boundaries, ${ }^{1}$

* Peter-Ben Smit is professor of contextual Biblical interpretation in the Dom Helder Cámara leerstoel at Vrije Universiteit Amsterdam and professor by special appointment of ancient catholic church structures and the history and doctrine of the Old Catholic Churches at Utrecht University; concurrently, he is dean of the diocese of Haarlem.

1 The considerations on which in the subsequent paper have been inspired to a significant extent by: Marianne Moyaert and Joris Geldhof (eds.), Ritual Participation and Interreligious Dialogue: Boundaries, Transgressions and Innovations, London: Bloomsbury 2015, a volume that does not, however, include an essay on early Christian sources. 
is as old as the emergence of 'Christianity' and occurs both in the lives of Jesus of Nazareth and the lives of the earliest Christian communities (or: early Jewish communities of Christ devotees). ${ }^{2}$ In this respect, a key text is 1 Corinthians 8 , in which important issues involved in transgressive ritual participation occur. It is a case of 'convivial promiscuity'. With that metaphor at least two things are drawn together: the association of idolatry with sexual infidelity in the rhetorical repertoire of Jewish anti-paganism, the frequent association of food with sexuality, and, by way of this association, the notion that the sharing of meals is often more than 'just eating together', it is a way of merging lives, convivencia, in other words. ${ }^{3}$ Such common life is manageable well in a community of a limited size and / or a homogenous character, preferably both. In the context of an expanding missionary movement, such as earliest Christianity, this poses all sorts of challenges, given that mission, at least when it is successful in at least the quantitative sense of the word, leads to ever larger and more diverse communities that interact in an increasingly diverse way with a growing number of contexts, or aspects of the same context, thus posing all sorts of challenges and giving rise to questions concerning the initial missionary tradition and its continuation. Such questions arise in particular when cases of doctrinal, ethical, or, in this case ritual boundary crossing occur, questioning distinctions and identities. Such boundary crossings are always intercultural, as the boundaries involved are related to particular (sub)cultures in a larger social whole; how they are evaluated depends on the views and sensitivities of the people involved - they are not negative or positive per se. All of this is very much the case in 1 Corinthians 8, where, due to missionary expansion, both at large (Paul's 'planting' of a church in Corinth) and at a smaller scale: diversification, or at least: diversity, within the Corinthian community itself, disagreement arises about how to relate to the 'outside world'.

2 I have explored questions of early Christian ritual and ritual failure elsewhere, notably in: 'Ritual Failure, Ritual Negotiation, and Paul's Argument in 1 Corinthians 11:17-34', Journal for the Study of Paul and His Letters 3/2 (2013), 165-195; 'In Search of Real Circumcision - Ritual Failure and Circumcision in Paul', accepted for publication in the Journal for the Study of the New Testament; 'Baptism and Ritual Failure in Romans 6', HTs Teologiese Studies / Theological Studies 72 (2016), http://dx.doi.org/10.4102/hts.v72i4.3237; 'Crucifiction? Crucifixion as a Failed Ritual in Phil. 2', Biblical Theology Bulletin 46 (2016), 12-24; in terms of the body of theory used and its presentation, some overlap exists. See in the first of these publications also references to recent literature on early Christian meals.

3 On this notion, see, e.g., Rudolf von Sinner, 'Trust and Convivencia: Contributions to a Hermeneutics of Trust in Communal Interaction', The Ecumenical Review 57 (2005), 322-341, see also: Theo Sundermeier, 'Konvivenz als Grundstruktur ökumenischer Existenz', in: Huber Wolfgang et al. (eds.), Ökumenische Existenz heute, München: Kaiser 1986, 49-10o. 
In this contribution, I will consider the dynamics of this text from the perspective of the study of ritual failure, which is part of the broader field of ritual criticism. ${ }^{4}$ As the term indicates, this particular field of study is concerned with what happens as soon as a ritual goes wrong — and a ritual goes wrong indeed in 1 Corinthians 8, with as a result the potential fall of Christ devotees in Corinth. In particular, I will focus on how Paul seeks to negotiate both the meaning of and the factual participation in the ritual of the (pagan) GrecoRoman meal, and thus attempts to formulate both a 'theological' approach to the issue at stake (probably more monotheistic and the apparently monolatreous attitude of the Corinthians $)^{5}$ that is true to his tradition and at the same time tries to outline a communal praxis that does justice to the building up of the community and the sensitivities that come with his own missionary outreach across the boundaries of Judaism into a realm in which non-existent deities could well be experienced as very real. ${ }^{6}$ In a(n inter)culturally and contextually sensitive way, Paul balances mission and tradition in the interest of building up the community of faith (or at least presents himself in a manner that can be understood in this way). How this is done is partially determined by the catalyst provided by ritual (and therefore theological or metaphysical!) negotiation necessitated by ritual failure due to transgressive ritual participation. In this way, the case of transgressive ritual participation in 1 Corinthians 8 is both problem and promise, as it causes problems and creates space for the discovery of new theological insight.

In order to do this, I will first consider the notion of ritual failure as it has been introduced by Grimes as a heuristic tool, then I will consider the interrelationship between ritual failure and transgressive ritual participation in 1 Corinthians 8, and finally I will formulate some conclusions as to this text and the ritual dynamics inherent to it. Prior to all of this, I will need to consider whether it is appropriate at all to use a ritual studies perspective for the analysis of early Christian texts.

4 On which, see, e.g., Roland Grimes, Ritual Criticism: Case Studies in Its Practice, Essays on Its Theory, Waterloo: Ritual Studies International, 2nd edition 2013 [1990]), as well as, Roland Grimes, The Craft of Ritual Studies, Oxford: Oxford University Press 2014, 71-75, 120-122, and especially Roland Grimes (ed.), When Rituals go Wrong: Mistakes, Failure, and the Dynamics of Ritual, Numen Book Series 115, Leiden: Brill 2007. Of relevance is also Kathryn McClymond, Ritual Gone Wrong: Case Studies in Ritual Disruption, forthcoming; Oxford: Oxford University Press 2015 .

5 Cf. Hans-Ulrich Weidemann, Taufe und Mahlgemeinschaft, Tübingen: Mohr Siebeck 2014, 301.

6 On the missionary dynamics, see, e.g., J. Kok, 'Mission and Ethics in 1 Corinthians: Reconciliation, Corporate Solidarity and Other-regard as Missionary Strategy in Paul', HTS Teologiese Studies / Theological Studies 68/1 (2012). 


\section{Ritual Studies and Early Christianity}

Before moving on to ritual failure and ritual negotiation in particular, it is necessary to outline some general characteristics of the value of ritual studies for the study of the New Testament. As can be easily observed, ritual studies and ritual criticism are slowly beginning to have a larger influence on New Testament studies, ${ }^{7}$ notwithstanding a heritage of suspicion vis-à-vis rituals in early Christianity. ${ }^{8}$ This is to be welcomed, as the study of rituals addresses an important aspect of many New Testament texts: So many texts are related to rituals, such as circumcision, sacrifice, baptism, and ritual meals. Even if the historical rituals to which New Testament texts refer are no longer directly accessible — as are all historical events 'behind' the texts — the study

7 See e.g. the overview of theories, which cannot be discussed in full here, provided by Risto Uro 'Ritual and Christian Origins', in: Dietmar Neufeld and Richard DeMaris (eds.), Understanding the Social World of the New Testament, London: Routledge 2010, 220-232, Benedikt Kranemann, 'Theologie nach dem Ritual Turn. Perspektiven der Liturgiewissenschaft', in: Judith Gruber (ed.), Theologie im Cultural Turn: Erkenntnistheologische Erkundungen in einem veränderten Paradigma, Frankfurt: Lang 2013, 151-173, and the overview offered by Jason T. Lamoreaux, 'BTB Readers Guide: Ritual Studies', Biblical Theology Bulletin 39 (2009), 153-165. See further also: Jonathan Klawans, Purity, Sacrifice, and the Temple: Symbolism and Supersessionism in the Study of Ancient Judaism, Oxford: Oxford University Press 2006), 17-73, Gerald Klingbeil, Bridging the Gap: Ritual and Ritual Texts in the Bible, Winona Lake: Eisenbrauns 2007, 45-126, DeMaris, 11-71 (referring to the 'embryonic character' of 'New Testament ritual criticism' on 4), as well as the contributions in: David Hellholm, Tor Vegge, Øyvind Norderval and Christer Hellhom (eds.), Ablution, Initiation, and Baptism, BzNw 176, Berlin: De Gruyter 2011). See further also: Soham Al-Suadi, Essen als Christusgläubige. Ritualtheoretische Exegese paulinischer Texte, Tübingen: Francke 2011, 49-109. In Old Testament studies, ritual theory is also making an impact, see, e.g., Klingbeil, Bridging the Gap, as well as Ithamar Gruenwald, Rituals and Ritual Theory in Ancient Israel, Leiden: Brill 2003.

8 See e.g., Anders Klostergaard Petersen, 'Shedding New Light on Paul's Understanding of Baptism: A Ritual-Theoretical Approach to Romans 6: 1-14', Studia Theologica 1 (1998), [3-28], $3-5$, suspecting that protestant prejudices and presuppositions played an important role in this respect, referring to J. Z. Smith's insightful comments in: Drudgery Divine. On the Comparison of Early Christianities and the Religions of Late Antiquity, Chicago: Chicago University 1990, 34. Also the encompassing overview of the discussion concerning early Christian initiation rites offered by Christian Strecker, 'Taufrituale im frühen Christentum und der Alten Kirche. Historische und ritualwissenschaftliche Perspektiven,' in: David Hellholm et al. (eds.), 13831440 , notes the necessity to take ritual seriously as such, rather than as a way of expressing dogma in a different way; the movement is rather the other way around (1420); therefore, ritual or liturgy appears as a kind of 'primary' theology. The general rituality of conversion, as noted by Strecker, is discussed more extensively by Thomas M. Finn, From Death to Rebirth: Ritual and Conversion in Antiquity, Mahway: Paulist Press 1990. 
of their probable shape and functioning can still inform the exegesis of the texts themselves. ${ }^{9}$ This is of significance, given that many early Christian texts are concerned with ritual. In fact, as will be argued below, many of the New Testament texts about rituals can be understood, not only as texts 'about' rituals, but also as part of a community's ritual praxis itself or a community's interpretation of a ritual praxis, given that the evaluation of a ritual belongs to such a ritual praxis, as will be argued below. Put differently: a text like 1 Cor. 11: 17-34 is not just about 'how Christians should celebrate a meal', or what the meaning of this meal is, but, precisely because it asks questions about ritual, about 'who Christians are'. The same applies to a text like Phil. 2: 5-11, it is not just a text that says something about how crucifixion functions, but it also says something about who Christians are as followers of the crucified (and exalted) Christ. ${ }^{10}$ Although this may be obvious to some, it is still worth stressing, given that the focus of much scholarship in New Testament studies is not necessarily focused on ritual matters and employing other than social-scientific or anthropological methods.

Accordingly, rituals are approached as such, rather than as, for example, as material vehicles for meaning that they convey in a symbolic way, as was, for example, argued forcefully and influentially by Mircea Eliade.11 Thus, a bias privileging the mind over that of the body and the spiritual over the material

With respect to this, the fact that one is dealing with texts, not the rituals themselves, does not need to be a problem, when e.g. Strecker's six ways in which text and ritual are, or can be, connected, are taken into account, most of which seem to apply to the text under consideration in this contribution. See Christian Strecker, Die liminale Theologie des Paulus. Zugänge zur paulinischen Theologie aus kulturanthropologischer Perspektive (= Forschungen zur Religion und Literatur des Alten und Neuen Testaments), Göttingen: Van den Hoeck und Ruprecht 1999, 78-80; DeMaris, 5-6, follows Strecker and gives a helpful English paraphrase. Streckers six ways are, in brief: (1) a text contains instructions for performing a ritual; (2) a text narrates the execution of a ritual; (3) a text debates the meaning or function of a ritual; (4) a text has its origins in ritual usage; (5) a text has itself a ritual function (e.g., a blessing or greeting); (6) a text makes use of ritual imagery or language (e.g., the libation in Phil. 2: 17-18). At least 1, 2 and 3 apply to 1 Cor. 8. See on the possibilities and restrictions of social-science methods for New Testament exegesis in general e.g. the succinct considerations of Stephen C. Barton, 'Social-Scientific Criticism,' in: Stanley E. Porter (ed.), Handbook to Exegesis of the New Testament, Leiden: Brill 2002, 277-289, as well as e.g. DeMaris, 5 , noting that anyone who studies the world 'behind' the text of the New Testament will have to take recourse to the analysis of ritual.

10 See on this topic, the argument of Peter-Ben Smit, Paradigms of Being in Christ: Paul's Use of Exempla in Philippians, London: Bloomsbury 2013, and Smit, 'Crucifiction?'.

11 See, e.g., the argument of Mircea Eliade, Images and Symbols: Studies in Religious Symbolism, New York: Sheed \& Ward 1961. 
is circumnavigated. Rather, in line with more recent theorizing about rituals, the proper character of rituals, notably in relation to the body, to bodily experience, and to enactment as a fundamental mode of identity, is stressed, following the lead of theorists such as Grimes, Bell, and Rappaport. Rappaport, for example, argues the following:

Ritual is not merely another way to "say things" or "do things" that can be said as well or better in other ways. The form that is ritual is surely without communicational equivalents and thus, possibly, without functional or metafunctional equivalents. That ritual's abilities are intrinsic to its form an in indissoluble association only with its form, goes far to account for is ubiquity. ${ }^{12}$

While this has become a commonplace among ritual scholars, it is still worth stressing in an interdisciplinary setting.

At the background of such insights, the 'rediscovery' of ritual in early Christian studies has rightly underlined the importance of rituals, such as baptism, meal fellowship, circumcision, etc., and the reflection upon them for the development of early Christian identity. Through the enactment or perform ance of a ritual, a community's identity is set in scene and reconstituted. ${ }^{13}$ What is enacted, may be described as the 'script' or 'grammar' - terms that are equivalent in this context - of a ritual. In the study of rituals, as well as in their actual functioning, these notions indicate a set of rules according to which a ritual needs to proceed in order to function (with regard to some rituals, the 'script' or 'grammar' has been made explicit to a very considerable extent see e.g. the use of a missal with its rubrics and, likely, introductory notes, for the performance of the ritual of the Mass, in other cases the 'grammar' remains much more implicit). Paying attention to this 'script' or 'grammar' is

12 Roy Rappaport, 'Enactments of Meaning,' in: Roy Rappaport, Ritual and Religion in the Making of Humanity, Cambridge: Cambridge University Press 1999, [104-138], 138, See also the broader argument of Frances Flannery, 'The Body and Ritual Reconsidered, Imagined, and Experienced,' in: Frances Flannery, Colleen Shantz and Rodney A. Werline (eds.), Experientia 1. Inquiry into Religious Experience in Early Judaism and Early Christianity, Atlanta: SBL 2008, 13-18, esp. 15, as well as the general theoretical background provided by Catherine Bell, Ritual Theory, Ritual Practice, New York: Oxford University Press 1992.

13 A very broad view of ritual reaches a point where nearly all behavior can be understood as the performance of an identity. See, e.g., Judith Lieu, Christian Identity in the Jewish and Greco-Roman World, Oxford: Oxford University Press 2004, 147-211, as well as, in relation to early Christian meals, Hal Taussig, In the Beginning was the Meal, Minneapolis: Fortress, 2009, 173-192, and Al-Suadi. 
helpful, as it sheds both light on a ritual's structure and because it provides a tool for the analysis of rituals:

ritual behaviour is structured and ... many of these structures can be represented in such a formalised way that general rules surface. The description and analysis of these structures and rules are nothing else than a grammar, the grammar of rituals ...14

This grammar, especially as it is used, explicitly or implicitly, by a community performing a ritual, also contains ascriptions of meaning to (parts of) a ritual, ${ }^{15}$ as well as expectations about the (desired) outcome of a ritual. ${ }^{16}$ For the latter reason, it is a particularly helpful notion for analyzing ritual failure, even if rituals are more than their (implied) scripts or grammars. Also, because the script or grammar of a ritual is related to expectations as to its outcome and performance, the notion of a ritual 'grammar' goes beyond being a 'mere' set of rules concerning ritual actions and makes perspicuous why also the evaluation of a ritual is an inherent aspect of its performance. When using the notion of 'grammar' in the sense proposed by Michaels, the impression that a ritual 'grammar' is entirely static can be avoided: it can change, even if it does so at a slower pace than its sequential performances. One reason for a grammar to change or be changed is precisely ritual failure and resulting ritual negotiation, as will become clear below. At the same time, due to its function as the set of norms inherent to the ritual, the grammar can also provide a corrective to particular kinds of its performance, should they be perceived as 'failures' or 'mistakes' when compared to earlier versions of the ritual or to its significance. ${ }^{17}$ In order to evaluate the identity that is constituted and exists concretely in its embodiment by people through the performance of a ritual according to a

14 Axel Michaels, 'A Preliminary Grammar of Newar Life-Cycle Rituals', Journal of Hindu Studies 5 (2012), [10-29], 11.

15 On the problems involved concerning ritual and meaning, see, e.g., Axel Michaels, 'Ritual and Meaning,' in: J. Kreinath, J. Snoek and M. Stausberg (eds.), Theorizing Rituals: Issues, Topics, Approaches, Concepts, Leiden: Brill 2006, 247-261.

16 On the language of 'script', 'grammar', its potential and limitations, see e.g. Axel Michaels, 'The Grammar of Rituals', in: Axel Michaels and Anand Mishra (eds.), Ritual Dynamics and the Science of Ritual, volume 1, Wiesbaden: Harrassowitz 2010, 7-28. - See on the expectations associated with a ritual also Ute Hüsken, 'Ritual Dynamics and Ritual Failure,' in: Ute Hüsken (ed.), When Rituals go Wrong: Mistakes, Failure, and the Dynamics of Ritual, Numen Book Series 115, Leiden: Brill 2007, [337-366], 350-353.

17 See Hüsken, 337 . 
particular grammar (or 'script'), it needs to be related to this 'script' or 'grammar' itself.

At this point, a potential criticism of the use of modern theories, such as theories concerning rituals and, below, ritual failure, to ancient texts, such as 1 Corinthians 8, namely the question as to the appropriateness of such a potentially anachronistic approach. While this question is certainly legitimate, it may also be considered answered by referring to the productive contribution that has been made by the application of sociological models to the study of the New Testament in general. ${ }^{18}$ The danger of anachronism, which lurks whenever a new model is applied to an old text, can be avoided by ensuring that the results from the (primarily heuristically oriented) use of a particular model in the exegesis of a text do indeed have a basis in the text itself and not in the model only. With regard to ritual criticism in particular, it may be noted that this field of study generally assumes the transcultural character of particular ritual patterns, which also legitimates the use of models stemming from the analysis of one culture or cultural group for the analysis of rituals of another culture or cultural group.

Having outlined all of this, the notion of 'ritual', as it was introduced above, can be specified somewhat more. A starting point can be found in Becker's statement that 'Ritual refers to an elaborate sequence of individual rites which, following an established ritual syntax, are logically connected within a certain functional context. ${ }^{\prime 9}$ Such an understanding, which depends on the notion of 'script' or 'grammar' as outlined above, can be developed further with the help of the theoretical framework provided by Michaels, who argues that rituals can be understood to have the following five characteristics: 1) Rituals are always related to causal change (causa transitionis), pertaining to circumstances that can be biological, physical, social, or natural in character; 2) A ritual is always intentional: some kind of ritual intention needs to be there and be expressed (solemnis intentio), examples are oaths, vows, promises, or verdicts; 3 ) A ritual is characterized by certain formal criteria of action, i.e., in order to be a ritual, an action must be stereotypical, formalized, repetitive, public, irrevocable, and often liminal (actiones formaliter riterorum); 4) Rituals are always contain modal criteria of action (actiones modaliter ritorum), expressing the functional dimension of rituals, pertaining either to 'societas' (functions of ritual relating to society: solidarity, hierarchy, control, standardization, etc.), 'religio' (rituals performed because of the transcendental value attached to them), or

18 See e.g. the considerations of Strecker, Theologie, 23-31.

19 See: Lamoreaux, 154. 
'impressio' (rituals understood in relation to the emotions of participants); 5) Rituals are related to change in identity, status, role, or competency (novae classificationes, transitio vitae $).{ }^{20}$

\section{Ritual Failure and Ritual Negotiation}

Ritual failure refers to cases in which a ritual is imperfectly performed, giving rise to its discussion and (re)negotiation in relation to the ritual community's developing identity (= 'ritual negotiation'). ${ }^{21} \mathrm{~A}$ fledgling field itself, this approach to rituals, especially as it is understood in this contribution, has yet to begin to be introduced into New Testament scholarship.

Rituals may fail due to a number of reasons all of which are related to the "grammar" of the ritual, including expectations with regard to its procedure, the persons and items involved, and the outcome. A broadly received proposal for the classification of ritual failure, or "ritual infelicities", to use his term, has been introduced by Grimes, who is widely regarded as one of the most important and influential theorists in the field of ritual studies. The typology that he offers includes a variety of kinds of failures that are not mutually exclusive; also, a ritual can be successful on one level for some and a failure on another level for others (e.g. a fertility ritual that fails to produce fertility, but does

20 See for this: Axel Michaels, 'Le rituel pour le ritual "oder wie sinnlos sind Rituale?"', in: Corinna Caduff and Johanna Pfaff-Czarnecka (eds.) Rituale heute: Theorien Kontroversen - Entwürfe, Berlin: Reimer 1999, 23-47, esp. 29-39, as well as Jens Kreinath et al., 295-296. This approach, which does not follow earlier 'grand unified theories' concerning the study of ritual, but focuses on a number of characteristics of rituals, can be justified by referring to the lack of any one current 'grand unified theory' for the exploration of ritual in the New Testament world and recent calls, such as by Uro for a 'piecemeal approach' to early Christian ritual that utilizes a combination of approaches and insights regarding ritual. See Uro, 234: 'Theoretical and methodological problems in the study of early Christian ritual can be best addressed by a piecemeal approach in which different aspects of early Christian behavior, as reflected in our sources, are examined in view of the insights and knowledge gained from ritual and cognate studies.' Grimes also offers a tentative definition of embodied, condensed, prescribed enactment, see: Grimes, Craft, 195, which certainly has its appeal, even if most of its aspects are also covered by Michaels' definition.

21 See on this, esp. Ute Hüsken and Frank Neubert, 'Introduction', in: Ute Hüsken and Frank Neubert (eds.) Negotiating Rites, Oxford: Oxford University Press 2012, 1-17. 
contribute to group cohesion), ${ }^{22}$ According to Grimes, the following cases of ritual failure can be distinguished: ${ }^{23}$

1. Misfire (act purported but void)

1.1. Misinvocation (act disallowed)

1.1.1. Nonplay (lack of accepted conventional procedure)

1.1.2. Misapplication (inappropriate persons or circumstances)

1.2. Misexecution (act vitiated)

1.2.1. Flaw (incorrect, vague, or inexplicit formula)

1.2.2. Hitch (incomplete procedure)

2. Abuse (act professed but hollow)

2.1. Insincerity (lack of requisite feelings, thoughts, or intentions)

2.2. Breach (failure to follow through)

2.3. 'Gloss' (procedures used to cover up problems)

2.4. 'Flop' (failure to produce appropriate mood or atmosphere)

3. 'Ineffectuality' (act fails to precipitate anticipated empirical change)

4. 'Violation' (act effective but demeaning)

5. 'Contagion' (act leaps beyond proper boundaries)

6. 'Opacity' (act unrecognizable or unintelligible)

7. 'Defeat' (act discredits or invalidates of others)

8. 'Omission' (act not performed)

9. 'Misframe' (genre or act misconstrued)

Before using this typology in the analysis of 1 Corinthians 8 , however, some further observations with respect to the nature of ritual failure should be made.

Starting with respect to the process of the analysis of ritual failure, it is of importance to note that the evaluation of rituals is an inherent part of the communities performing them; according to Hüsken,

Evaluation is an intersubjective process, executed by groups or individuals. It is based on certain sets of values which might stem from canons

22 See the foundational contribution of Ronald L. Grimes, 'Infelicitous Performances and Ritual Criticism,' in his Ritual Criticism: Case Studies in Its Practice, Essays on Its Theory, Columbia: University of South Carolina Press 1990, [191-209], 205-207. See also the theoretical considerations offered by Michael Ing, The Dysfunction of Ritual in Early Confucianism, Oxford: Oxford University Press 2012, 38-56.

23 For the typology, see: Grimes, 'Performances,' 204-205. The ritual theory followed here is indebted to Ute Hüsken, 'Ritual Dynamics and Ritual Failure,' in: Hüsken, 337-366, for which Grimes, 'Performances,' forms an important background. 
which the participants themselves have not created, but it might equally be based on the expectations, intentions and agenda of individual participants ...24

Or, as Grimes has it 'Ritual criticism goes on informally all the time, and its contexts are various - both popular and scholarly. Criticism is not restricted to scholars. Ritual criticism is implicit in the normal course of conserving, transmitting, enculturating, and adapting rites. ${ }^{25}$ In other words, the attribution of failure or success to a ritual is not an extraneous scholarly classification, but inherent to the ritual and its performance. ${ }^{26}$ This notwithstanding, a ritual can fail for outsiders in some ways in particular, for example because it is unintelligible to them (category 6 'opacity'), or because it constitutes a violation (category 4), which may not be the case for those actually engaged in the ritual; also 'misframing' (category 9) is a category particularly relevant for outsiders evaluating a ritual — but, again, is not limited to outsiders alone At the same time, a ritual can fail and be successful simultaneously depending on the criteria that are applied in its evaluation. ${ }^{27}$

Furthermore, as Hüsken, has pointed out based on the analysis of a collection of studies on ritual failure, cases of rituals going awry contribute much to the discovery of the meaning of a ritual for a community and to the further development of the rituals as such. As she states:

$[\mathrm{P}]$ articipants and spectators alike learn more about the 'correct' performance of a ritual by deviating from, rather than by adhering to the rules. One might even say that solely the definitions and examples of 'ritual failure' and 'error' — and how they are coped with — prove the existence of decisive norms for ritual actions, even when the former are imagined deviations from imagined norms.... 'Failed ritual' directs our attention to 'what really matters' to the performers and participants and others in one way or another involved in a ritual. ${ }^{28}$

\footnotetext{
24 Hüsken, 339.

25 Roland L. Grimes, 'Response to the contributions presented on the occasion of the panel 'Ritual Mistakes and Failures' during the AAR conference, held in November 2004 in San Antonio (Texas),' [unpublished], quoted by Hüsken, 339.

26 See Hüsken, 338-341, following Grimes, 'Response.'

27 See further also Hüsken, 353, 361.

28 Hüsken, 337.
} 
Another aspect of the dynamics involved in the detection and discussion of ritual mistakes or ritual failures that is of significance is that of the ritual competence that performers of rituals and / or its critics have (or claim) and / or deny others. Only 'ritual specialists' may be seen to have the right to deviate from ritual norms, others may be regarded as lacking this specific authority. ${ }^{29}$ As Hüsken points out:

Frequently, if not always, the social and political standing of individuals and groups beyond the ritual context are negotiated through the evaluation of ritual. Not only the ritual process, but also the authority and authenticity of the ritual experts, and hierarchies among the participants (or the groups which are represented by them) are evaluated and, eventually, reorganized. Moreover, whose definition of 'right' and 'wrong' has a lasting impact on a ritual tradition reveals how the power relations in the wider socio-cultural field are structured. This close connection of ritual and its [social] context accounts for the fact that deviations from a prescribed ritual procedure are often purposely employed in order to challenge the form of the rituals and through it the prevalent power relations as well. ${ }^{30}$

Finally, the 'creative power of deviations' should be considered..$^{31}$ This is an important aspect of the dynamic of 'ritual failure', given that 'breaches of [ritual] rules can - and frequently do - instantiate the creation of new ritual rules in practice. ${ }^{32}$ Of interest is also Hüsken's remark that such creation of new ritual rules takes place 'frequently under the pretext of "returning to older (severer) rules." 33 Thus, the breaking of ritual rules and their correction can be seen as a creative process as well, in which new ritual forms are created, or new meaning is given to rituals. This creative aspect of ritual failure is closely related to the second aspect of ritual studies that is of significance here: 'ritual negotiation' that will be introduced now.

'Ritual negotiation' has been described by Hüsken and Neubert as the process of 'interaction during which differing positions are debated and / or acted out' in relation to a particular ritual and the community performing it, noting that 'a central feature of ritual is its embeddedness in negotiation processes,

\footnotetext{
29 Hüsken, 344-346, 361.

3о Hüsken, 361-362.

31 See for this and the following: Hüsken, 346-347.

32 Hüsken, 346.

33 Hüsken, 346.
} 
and that life beyond the ritual frame often is negotiated in the field of rituals. ${ }^{\prime 34}$ These insights further develop three aspects of what is already brought to the fore by the study of ritual failure:

1) the importance of rituals as a focus for the (re)negotiation of the life of a community or group;

2) the significance of power relations with regard to the performance and criticism of ritual;

3) the importance of (perceived) failure and disagreement for triggering critical thinking and reflection. ${ }^{35}$

It goes without saying that such (re)negotiation of rituals also points to the often masked but fundamental instability and fluidity of rituals and their performance. Initial explorations in the field of 'ritual negotiation' have led to the identification of three main themes associated with it:

1) Questions of participation, both in the ritual as well as in processes of negotiation regarding it often are of central importance;

2) Questions relating to the subversion of ritual prescriptions, ritual roles, and the power relations surrounding the ritual performances ${ }^{36}$ often seem to be the trigger of processes of ritual negotiation;

3) Questions concerning the context of a ritual, specifically the web of social (power) relations within which it has a place and the kind of differences it negotiates move to the foreground more when processes of ritual negotiation are taken into account.

Finally, it must be underlined that ritual failure is always ritual failure from someone's perspective. A ritual can be perfectly fine from one person's perspective and a profound failure from someone else's. A point in case would be 1 Cor. 11: 17-34, where Paul addresses complaints about the Corinthian meal fellowship, which is held in a manner that is offensive to some, but, as Paul needs to (or feels the need to) provide instructions, obviously not to all. In fact, his proposal may be considered a ritual infelicity by those whom he addresses. ${ }^{37}$ In what follows, the focus will be on Paul's perspective - the only perspective of which the representation is beyond doubt in the text (Paul may well frame

\footnotetext{
34 Hüsken and Neubert, 1.

35 See Hüsken and Neubert, esp. 1-4.

36 Hüsken and Neubert, 4.

37 On which, cf. Smit, 'Failure'.
} 
the perspectives and positions of others to suit his rhetorical aims) - , well aware of the fact that his is just one voice in the Corinthian discussion.

\section{Transgressive Intercultural Ritual Participation and Ritual Failure in 1 Corinthians 8}

Having thus outlined the appropriateness of using a ritual approach to early Christian texts as well as the particularities of the topic of ritual failure, now both transgressive ritual participation and ritual failure in 1 Corinthians 8 , a section of 1 Corinthians clearly marked off from the preceding sections by the

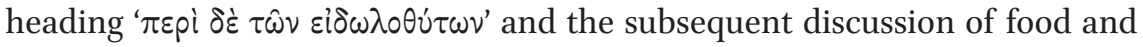
wages due to the change of subject (rhetorical question in 1 Cor. 9:1), ${ }^{38}$ can be considered. In order to give a general impression of the text, it follows here in both Greek and English (NRSv):

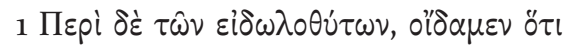

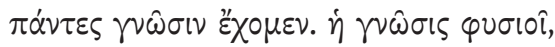

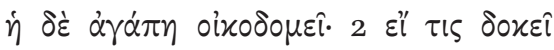

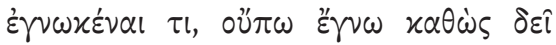

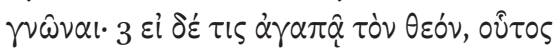

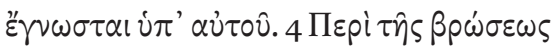

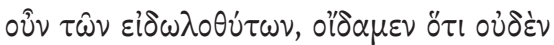

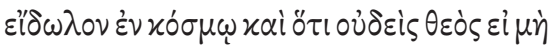

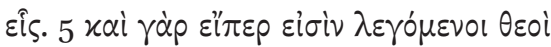

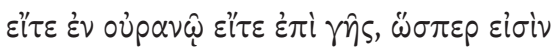

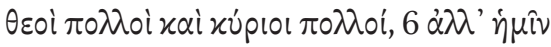

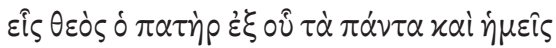

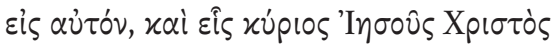

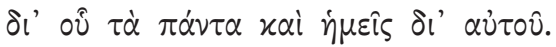

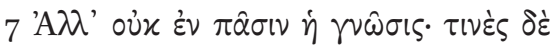

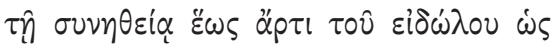

1 Now concerning food sacrificed to idols: we know that "all of us possess knowledge." Knowledge puffs up, but love builds up. 2 Anyone who claims to know something does not yet have the necessary knowledge; 3 but anyone who loves God is known by him. 4 Hence, as to the eating of food offered to idols, we know that "no idol in the world really exists," and that "there is no God but one." 5 Indeed, even though there may be so-called gods in heaven or on earth - as in fact there are many gods and many lords -6 yet for us there is one God, the Father, from whom are all things

38 Chapter 9 serves to further support Paul's call for self-restraint on the part of the 'strong' and Chapter 10 deals with a related, yet distinct situation (participating in the actual sacrificial acts), cf. David G. Horrell, 'Idol-Food, Idolatry and Ethics in Paul', in: Stephen C. Barton (ed.), Idolatry. False Worship in the Bible, Early Judaism and Christianity, London: T\&T Clark, 2007, [120-140], 125-126. See also: Derek Newton, Deity and Diet: The Dilemma of Sacrificial Food at Corinth, Sheffield: Sheffield Academic Press 1998, 314-324. 


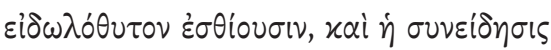

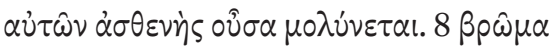

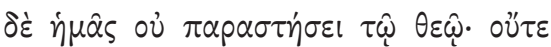

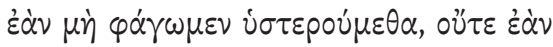

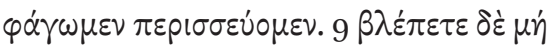

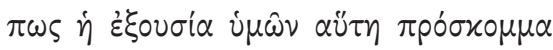

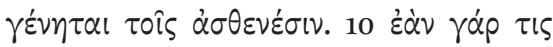

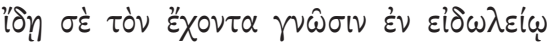

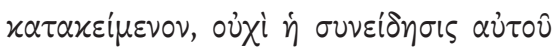

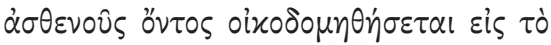

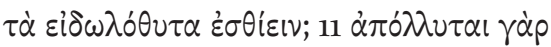

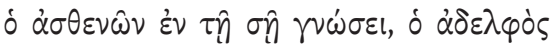

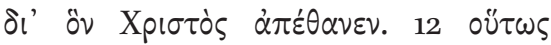

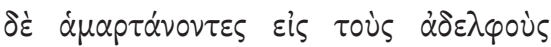

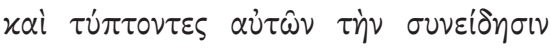

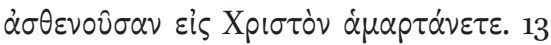

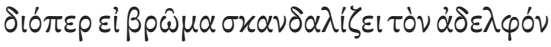

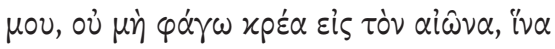

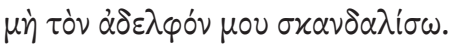

and for whom we exist, and one Lord, Jesus Christ, through whom are all things and through whom we exist. 7 It is not everyone, however, who has this knowledge. Since some have become so accustomed to idols until now, they still think of the food they eat as food offered to an idol; and their conscience, being weak, is defiled. 8 "Food will not bring us close to God." We are no worse off if we do not eat, and no better off if we do. 9 But take care that this liberty of yours does not somehow become a stumbling block to the weak. 10 For if others see you, who possess knowledge, eating in the temple of an idol, might they not, since their conscience is weak, be encouraged to the point of eating food sacrificed to idols? 11 So by your knowledge those weak believers for whom Christ died are destroyed. 12 But when you thus sin against members of your family, and wound their conscience when it is weak, you sin against Christ. 13 Therefore, if food is a cause of their falling, I will never eat meat, so that I may not cause one of them to fall.

When looking at what goes wrong here ritually speaking, the case seems to be rather precise, as Paul indicates it in his introduction in 1 Cor. 8: 1: ' $\pi \varepsilon p i$

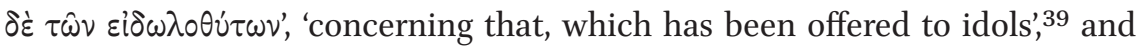
further determines it in verse 13 , where specifically meat (

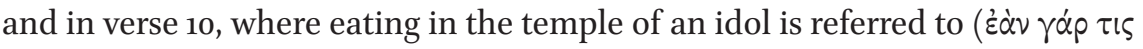

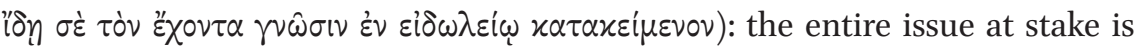

39 Cf. for a more detailed consideration: Anthony C. Thiselton, The First Epistle to the Corinthians, Grand Rapids: Eerdmans 2000, 617-620; here the association of foodstuffs with an 'idol' is of key importance. 
presumably participation in meals in temple precincts, ${ }^{40}$ where meat was consumed that had been offered or sacrificed to the appertaining deity by those who also participated in the xupıx<ov $\delta \varepsilon i \pi v o v$ ( 1 Cor. 11: 20), as it was held by the Corinthian Christians, thus causing confusion and potential defection from their allegiance to Christ among those who ascribe real existence and influence to the 'idols' (vv. 10-13), the so-called 'weak' in this text. The latter is the point at which ritual failure happens: the ritual participation of the so-called 'strong' in Corinth is detrimental to the 'weak'.

At this point, it should be noted that whereas Paul is, in 1 Cor. 8:1-13, primarily discussing the question of participation in meals involving food offered to 'idols', one could argue that what he is really doing is defending the integrity and ritual efficacy of the Lord's Supper and attempting to avoid its failure as a ritual creating and expressing the unity of the community of Christ devotees and their sole allegiance to the Lord Christ. However, the communal meal of the early Christian community as such is not mentioned here, nor is it contrasted with other meals, rather, the focus is on participation in meals involving food offered to idols as such. Paul does, to be sure, address the other issue in 1 Corinthians as well, but only in Chapter 10 (esp. vv. 14-22), which is both related to and separated from Chapter $8 .^{41}$ However much the Lord's Supper may be at the background of Paul's argument in 1 Corinthians 8, here the focus will be on what he has to say and does say about 'pagan' meals, rather than what he might want to say, but does not say here about the Lord's Supper.

When returning to Paul's argument in 1 Cor. 8:1-13 and ritual, then, the following may be observed. To begin with, the participation of the 'strong' in meals involved food offered to idols could, primarily from the perspective of the 'weak' (ritual always fails from a particular perspective, not necessarily in general), ${ }^{42}$ be seen as a case of 'abuse', in particular because the ritual does not lead, at least within the Corinthian community, to group coherence. Therefore it 'flops' ( 2 and 4). Alternatively, it could be argued to be effective to some (the 'strong'), but demeaning to others (the 'weak') and hence fit the category of

40 Cf. for this emphasis also Matthias Konradt, Gericht und Gemeinde: Eine Studie zur Bedeutung und Funktion von Gerichtsaussagen im Rahmen der paulinischen Ekklesiologie und Ethik im 1 Thess und 1 Kor., Berlin et al.: De Gruyter 2003, 345. See also Newton, 296305 , for a consideration of the significance of place, taking into account archeological evidence.

41 See the succinct overview of the structure in Al-Suadi, 272-273 and Matthias Klinghardt, Gemeinschaftsmahl und Mahlgemeinschaft: Soziologie und Liturgie frühchristlicher Mahlfeiern, Tübingen: Francke 1996, 344.

42 Newton, 280 , rightly refers to the ambiguity of the reality of the idols (as objects) and the deities that they are associated with. 
'violation' (4). It might also be profitable, possibly even the most profitable, to consider it from Paul's perspective, who seems to indicate that a profound misunderstanding of this ritual participation and its metaphysical implications on the part of the 'weak' is at stake, even if this understanding is quite understandable in itself (v. 7). This leads one to considering categories such as 'opacity' (6), 'defeat' (7), and 'misframing' (9). All three of these categories seem to elucidate what Paul writes. The participation of the 'strong' in meals associated with lords other than Christ fails for the weak because they do not understand it, i.e., they do not have (or 'possess') ${ }^{43}$ the required knowledge (v. 1) that Paul and the 'strong' share, ${ }^{44}$ therefore, what the 'strong' are doing, in reality: just eating meat, without recognizing any other lord but Christ, given that the other deities do not really exist, appears to them as something that it is not comprehensible. While this could be argued to constitute a case of 'opacity' (6), the 'weak', in fact, go further than their non-understanding of what goes on: they also attribute a wrong meaning to it and, due to this, it fails, given that it damages their conscience and faith. This can well be regarded as a case of 'misframing': the 'weak' regard the participation of the 'strong' in meals associated with lords other than Christ as cultic promiscuity, given that they attribute real existence to the 'idols' involved, rather than to deny such existence based on the knowledge that Paul and the 'strong' share (v. 1). Misframing leads to ritual failure in this case. The effect of this misframing can be elaborated further when considering a further and final category of ritual failure: defeat. Defeat indicates the voiding of one ritual because of the performance of another, usually stronger, one. This indeed is the case in Corinth as well: the exclusive allegiance to Christ, ritually performed at the 'Lord's Supper' seems to be defeated by the participation in a meal associated with another deity. The reason for this perspective on what the 'strong' are doing is, again, misframing due to insufficient knowledge, ${ }^{45}$

43 Cf. Thiselton, 621.

44 Cf. Weidemann, 300; the reference to 'all' in v. 1 is probably a captatio benevolentiae rather than an empirical statement about the knowledge present in the Corinthian community, however. Alternatively, it could be argued, with Al-Suadi, 274-275, that all have knowledge, but not all apply it or allow their consciences to be guided by it. - As Konradt, 350-351, suggests, the knowledgeable or those using their knowledge may well have been the economic and social elite of the community as well. - Whether or not 'Gnosticism' is at the background of this all is for the argument set forth here of limited importance, cf. however Wolfgang Schrage, Der erste Brief an die Korinther, volume 2, Neukirchen: Neukirchener Verlag 1995, 218-220 (also on economic aspects of access to foodstuffs).

Cf. Newton, 290-293, suggesting that in v. 7 Paul addresses a particular kind of knowledge, which the weak lack, based on the use of a definite article to indicate the knowledge at stake. 
but its effects are no less dire, especially due to the fact that whereas opinions as to the reality of deities could differ, the practice of eating food offered to idols was one that left much less leeway in early Judaism and not doing so was an important identity marker. ${ }^{46}$ The Corinthian problem could only arise because an embodied practice was involved, not just a difference of theoretical opinion. In fact, the entire issue at stake could well be understood as resulting from a tension between (theoretically) shared insight and divergent practices in relation to it. ${ }^{47}$ The divergence may well have to do with the significance of non-participation in meals associated with idols in early Judaism, which, as a practice, trumped theoretical convictions for some.

When turning to Paul's reaction to the transgressive ritual participation in Corinth and its effects, a blurring of boundaries and allegiances that are detrimental to group identity, coherence, and allegiance, two aspects stand out in particular. The first concerns Paul's metaphysical appraisal of the situation at stake, which involves the participation of members of the Christian community in Corinth in both the meal of the Lord Christ (see 1 Cor. 11) and the meals associated with other xúpror (see v. 5). His position seems (!) to be rather straightforward and with it, he positions himself within the spectrum of possible positions regarding the reality of plurality of deities in the Greco-Roman world:48 'idols' have no claim to reality and there is but one God: 'we know that "no idol in the world really exists", and that "there is no God but one".' (v. 4).49 The Corinthians, presumably the 'strong' are addressed in particular here, and

46 See with this emphasis: Schrage, 218.

47 Cf. Thiselton, 6og-610.

48 On which, see, e.g., Emma Wasserman, " "An idol is nothing in the world" (1 Cor. 8: 4): the metaphysical contradictions of 1 Corinthians 8:1-11:1 in the context of Jewish idolatry polemics', in: Susan E. Myers (ed.), Portraits of Jesus, Tübingen: Mohr Siebeck 2012, 201227; Johannes Woyke, 'Das Bekenntnis zum einzig allwirksamen Gott und Herrn und die Dämonisierung von Fremdkulten: Monolatrischer und polylatrischer Monotheismus in 1. Korinther 8 und 1o', in: Jörg Rüpke (ed.), Gruppenreligionen im römischen Reich, Tübingen: Mohr Siebeck 2007, 87-112; Ook: Bert Jan Lietaert Peerbolte, 'Jewish Monotheism and Christian Origins', in: Alberdina Houtman, Albert de Jong and Magda Misset-van de Weg (eds.), Empsychoi Logoi - Religious Innovations in Antiquity. Studies in Honour of Pieter Willem van der Horst, AJEC 73 (2008), 227-246, as well as Hein Versnel, Coping with the Gods, Leiden: Brill 2011. — Given the fact that a whole range of possible opinions existed within contemporary Judaism; at stake in 1 Cor. 8 is, therefore, not a tension between 'Christianity' and 'Judaism', but a discussion very much within the context of Hellenistic Judaism itself. — For emphasis on the intercultural dimensions of the Corinthian confusion and misunderstandings, see: Newton, 280-282.

On the tradition-historical background, see, e.g., Schrage, 222-225. - For instance, Thiselton, 608, rightly notes that this is likely the content of the knowledge that all share. 
Paul share this knowledge (o' $\delta \alpha \mu \varepsilon v) .{ }^{50}$ To be sure, this position of Paul must have constituted a rather profound kind of ritual failure from the perspective of (at least some) other participants in the temple meal, given that Paul and those congenial to him certainly do not have the expected intention, not even in the most formal and minimalist way possible, of associating with the deities involved, as they do not recognize them as such. This may well be captured by Grimes' category 2.1.: insincerity. Although Paul seems to be convinced of the tenability of his position, he also is aware of others that may feel differently, or at least interpret the transgressive ritual actions of the 'strong' along different lines. Accordingly, Paul nuances this position in the face of the social reality of Corinth (as he understands and presents it) in the two subsequent verses, adopting a position that is monotheistic in its core, but which allows for a more monolatreous position and the experience of the reality of other deities but God, it seems, which he is forced to do vis-à-vis the reality of the rather densely populated religious world of Corinth (and the Greco-Roman world at large):

Indeed, even though there may be so-called gods in heaven or on earth as in fact there are many gods and many lords - yet for us there is one God, the Father, from whom are all things and for whom we exist, and one Lord, Jesus Christ, through whom are all things and through whom we exist (vv. 5-6).

In doing so, he can be seen as balancing two things: the metaphysical convictions stated in v. 4 and the tension that the Corinthian community, or at least part of its members, experience and are accustomed to when confronted with various xúpıol, their claims to power (social, religious, magical) and their factual influence over their lives, as Paul puts it in v. 7:

Since some have become so accustomed to idols until now, they still think of the food they eat as food offered to an idol; and their conscience, being weak, is defiled. ${ }^{51}$

50 Cf. also Newton, 284-29o.

$5^{1}$ See on the weak, e.g., Mark D. Nanos, "The Polytheist Identity of the "Weak" and Paul's Strategy to "Gain" them: A New Reading of 1 Corinthians 8: 1-11: 1', in: Stanley E. Porter (ed.), Paul:Jew, Greek, and Roman, Leiden: Brill 2008, 179-210. See also the sketch in Konradt, 356, and in Schrage, 254-256. 
If someone or something walks like a xúpı a kurios, ought it not to be regarded as a xúplos?52 And would association with such a factual xúpros not compromise once allegiance to the one and only true xúpıos? Paul's formal metaphysical position leaves lots of room for transgressive ritual participation (even this takes place at the cost of denying the value of the ritual praxis of the 'other'), given that it denies the metaphysical reality of the 'other' ritual in which a person participates..$^{53}$ Nonetheless, he is keen to restrict the use of this room, due to his understanding of the social reality of Corinth, ${ }^{54}$ and the possible perception of other deities by members of the community. ${ }^{55}$ This brings one to the second aspect of the dynamics provoked by transgressive ritual participation that Paul addresses in 1 Corinthians 8: that of group solidarity and the preservation of group boundaries in the interest of preserving group coherence. ${ }^{56}$ Transgressive ritual participation always has to do with crossing boundaries; crossing boundaries, however, always has to do with a renegotiation of the self-positioning of a group within a broader spectrum of groups in society. If some members of a group cross boundaries, ritually, in this case, in a way that cannot be followed by others, group coherence suffers and the sense of identity that group members derive from their mem-

52 Cf. also the nuanced exegesis of Schrage, $235-238$, noting that the statement that there are not really 'gods and lords' is used by Paul in a distinct way: 'Er gilt für die Christen, die sich zu dem einen Gott und einen Herrn bekennen. Für andere gibt es realiter durchaus 'sogenannte Götter und Herren ... ja selbst Christen sind ihrer Macht ausgesetzt, verweigern ihnen aber die Anerkennung' (emphasis in original) Cf. also the congruent reflections of Thiselton, 629-633.

53 Others see the context differently, e.g., George Heyman, The Power of Sacrifice: Roman and Christian Discourses in Conflict, Washington, DC: The Catholic University of America Press 2007, 229, who argues that Paul also assumes in 1 Cor. 8 that real fellowship between a real idol (even if not truly a deity) and the 'Christian' in question is at stake. This, however, does not seem to be the case, just like it is not the case in 1 Cor. 10 (see esp. vv. 23-33), the point is much rather that the people are getting the wrong impression about allegiance to Christ and what it implies considering one's evaluation of other deities and fellowship with them.

54 Cf. Hal E. Hausig, In the Beginning Was the Meal, Minneapolis: Fortress 2010, 168: 'Paul seemed to be quite consistent in that he did not want food to interfere with the relationships of those who eat together.'

55 Cf. also Al-Suadi, 274-275, Konradt, 355. Schrage, 239-240, rightly notes: 'mit $\lambda \varepsilon \gamma o ́ \mu \varepsilon v o r$ wird ihre [sc. der Götter und Herren] Würde und Gotteheit, nicht ihre Existenz und Mächtigkeit bestritten.'

56 Cf. Hans-Joachim Stein, Frühchristliche Mahlfeiern: Ihre Gestalt und Bedeutung nach der neutestamentlichen Briefliteratur und der Johannesoffenbarung, Tübingen: Mohr Siebeck 2008, 102, followed by Al-Suadi, 277 . 
bership of the group is diminished, ${ }^{57}$ accordingly, they may fall. ${ }^{58}$ It is precisely this that Paul addresses when he writes:

9 But take care that this liberty of yours does not somehow become a stumbling block to the weak. 10 For if others see you, who possess knowledge, eating in the temple of an idol, might they not, since their conscience is weak, be encouraged to the point of eating food sacrificed to idols? 11 So by your knowledge those weak believers for whom Christ died are destroyed. 12 But when you thus sin against members of your family, and wound their conscience when it is weak, you sin against Christ. 13 Therefore, if food is a cause of their falling, I will never eat meat, so that I may not cause one of them to fall.

These considerations of Paul lead to considering another aspect of ritual failure. In brief, Paul argues that causing a member of the community to stumble through one's participation in meals involving food offered to idols is an offense against Christ, even if it can be regarded as inoffensive in itself. ${ }^{59}$ Some of Grimes's categories can elucidate this, such as 'violation' (4) an act that has a demeaning effect, or as a 'flop', a ritual act that does not produce the expected atmosphere or mood, to the extent of damaging the communion between the believer and Christ. ${ }^{60}$ Even if Paul does not use language of the body of Christ here explicitly, it may well provide the conceptual background for his line of thought. ${ }^{61}$

Despite his strong sentiments and injunctions in vv. 9-13, however, Paul can be seen as steering a middle course, one the one hand taking the same philosophical or metaphysical position as the 'strong' in Corinth, while on the other hand arguing in favour of temperance regarding their transgressive ritual participation and what may be termed an ascetic attitude concerning food in

57 Cf. also Horrell, 128, noting that Paul's line of argument is 'entirely relational'. For a similar argument, cf. also Newton, 307-309. Both Horrell and Newton note that the 'weak' thus gain substantial influence in the community. On emphasis on the role of the 'other' in this and other sections of the letter, see also Thiselton, 607 .

58 Cf., e.g. Schrage, 263-266, Thiselton, 649-654.

59 Cf. also Konradt, 358: something that would, considered individualistically, be soteriologically irrelevant (v. 8) becomes soteriologically very relevant indeed because of the social shape of 'salvation-in-communion'.

60 Cf. Horrell, '133: '[I]nsofar as it (sc. idol-food) is idol worship, seen as participation in a

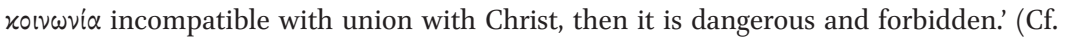
also Horrell, 139).

61 Cf. Al-Suadi, 278. 
order to preserve the sense of identity that other group members derive precisely from a strict observance of the ritual group boundaries vis-à-vis association with other kurioi through the consumption of food offered to them. ${ }^{62}$ In doing so, Paul seeks to avoid ritual failure in terms of the participation of some community in meals associated with lords other than the Lord Christ, given that these, while in principle theologically / metaphysically possible and relatively harmless, are detrimental to group coherence.

Having now discussed both what goes on in terms of ritual failure in 1 Corinthians 8 and Paul's reaction to it, it can be asked what further light the above consideration may shed on both 1 Corinthians 8 and on the dynamic of transgressive ritual participation as a phenomenon.

\section{Ritual Negotiation in 1 Corinthians 8: Concluding Observations}

First of all, as cannot be emphasized enough with regard to the study of early Christianity: ritual and ritual participation, which have become problematic due to (increasing) cultural diversity in the Corinthian community, likely due to its missionary dynamics, is the catalyst for Paul's theological reflection and cybernetic instructions in 1 Corinthians 8 . The knowledge that he refers to in 1 Corinthians 8 becomes relevant first and foremost because of the intercultural and transgressive ritual behaviour of some community members and the issue that others take with this, apparently seeing boundaries where others do not and considering crossing them as something negative (obviously differing from those that do the crossing). Rather than just being the adiaphoric and outward expression of in inwardly held essential faith, ritual practice is here very much the performance or enactment of that faith which determines cultic allegiance and group cohesion in a way that knowledge as such cannot (see vv. 1.7). To the extent that love ( $\dot{\alpha} \gamma \dot{\alpha} \pi \eta)$, as it appears in the maxim that Paul quotes, also refers to a communal praxis of self-restraint (see, e.g., 1 Cor. 13), it indicates the same. Real knowledge is conditioned by love. ${ }^{63}$ As part of the development of early Christian ritual, of which 1 Corinthians is full (see also Chapters 10, 11, and 14 of this letter), early Christian 'theology' is being developed, both of which are very much in flux, it seems.

Second, the analysis of the process of ritual failure and consequential ritual negotiation seems to lead to new insights into the text. First, the maxim

\footnotetext{
62 Similarly: Schrage, 268.

63 Cf., e.g., the extensive argument of Newton, 274-277, see also Schrage, 230-231, or Thiselton, 626-627.
} 
that Paul uses at the beginning of his deliberations, $\dot{\eta} \gamma \nu \omega \hat{\omega} \sigma \iota \varsigma \varphi v \sigma 10 \hat{\imath}, \dot{\eta} \delta \dot{\varepsilon} \alpha \gamma \dot{\alpha} \pi \eta$

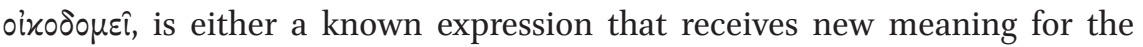
Corinthians and Paul in a new context, or it is a new summary of theological insight that Paul will use as a vantage point for the remainder of his argument. Even so, v. 1 contains at the very least a new articulation of older tradition, which, in v. 13 gives rise to a new ritual praxis: abstention from meat, at the very least in temple precincts - presumably a proposal with socio-economic consequences as well, given that meat was a luxury product and its consumption an indicator of social and economic status. ${ }^{64}$ Paul thus moves the Corinthian 'strong' from an understanding of 'religion' that has primarily to do with insight and knowledge to an understanding of the same that puts communal praxis and relations at the first place; this amounts to an attempt at a virtual redefinition as to what 'religion' might have meant to this part of his audience and entails a different 'dogmatic' emphasis and a different ritual praxis, both of which go hand in hand. All this being due to ritual failure, transgressive ritual participation, and ritual negotiation. - Whether Paul was successful, is, of course, quite another question.

Third, the new, inclusive praxis, characterized by self-restraint, is argued for by Paul in a deeply theological, rather than primarily pragmatic way; this is apparent from both his metaphysical and, if you like, ecclesiological and hamartiological considerations concerning the gravity of making someone stumble. ${ }^{65}$ This indicates the high importance of theological, or, if you like, ideological discourse when it comes to dealing with ritual, both by experts and leaders such as Paul, but also by others, including both the 'weak' and the 'strong', as is apparent from Paul's representation of their respective positions and attitudes that touch on all sorts of questions of fundamental and systematic theology. - Even if Paul could, in theory, be open for the kind of intercultural ritual transgression that the 'strong' undertake, in the end he is very wary of it, in order to safeguard all the members of the Corinthian community of Christ devotees. As much as Paul is himself a boundary crosser and an intercultural, hybrid missionary — here he draws a line.

64 See for some considerations on this topic: Sung Uk Lim, "The Political Economy of Eating Idol Meat: Practice, Structure, and Subversion in 1 Corinthians 8 through the Sociological Lens of Pierre Bourdieu', Horizons in Biblical Theology 34 (2012), 155-172. — The material dimension of 1 Cor. 8 could be discussed in more depth, given that it is precisely matter and its treatment (meat, in this case) that defines boundaries and religious allegiances, while it also is the vehicle for the performance of group identity.

65 See the formulations of Konradt, Gericht, $360-361$. 
Fourth and finally, it ought to be underlined that the entire problem in 1 Corinthians 8 has arisen not merely because of differences in theological insight, but also because of cultural difference and the dynamics of negotiating intercultural encounter, which have everything to do with the missionary dynamics of early (Pauline) Christianity; Paul, operating on the basis of one of multiple possible early Jewish positions concerning food laws and the treatment of idols, has now entered into a realm in which idols are experienced as very real by a number of Christ devotees (v. 7), while others, in line with Paul's own insight (v. 4), do not share this at all. Different, culturally influenced positions and practices, including transgressive ritual participation, thus leads to ritual failure, to which only an inter-culturally sensitive solution, as which the one proposed by Paul can be seen, can be an appropriate answer. This solution also implies the discovery of new aspects of what identity 'in Christ' can mean in a profoundly 'pagan' and polytheistic setting; mission and ritual together provide, thus, important impulses for the development of early Christian life and thought. ${ }^{66}$

66 Also, for contemporary reflection on culture, ethnicity, and Christianity, 1 Cor. 8 is of relevance, see, e.g., Maureen W. Yeung, 'Boundaries in "in-Christ identity": Paul's view on table fellowship and its implications for ethnic identities,' in: Richard R. Cook / David W. Pao (ed.), After Imperialism: Christian Identity in China and the Global Evangelical Movement (Eugene, OR: Pickwick, 2011), 154-174. 